\title{
Regional scale effects of base cation fertilization on Norway spruce and European beech stands situated on acid brown soils: soil and foliar chemistry
}

\author{
Laurent Misson*, Quentin Ponette and Frédéric André \\ Université catholique de Louvain, Unité des eaux et forêts, Place Croix du Sud, 2 bte 9, 1348 Louvain-la-Neuve, Belgium
}

(Received 12 February 2001; accepted 20 June 2001)

\begin{abstract}
Ten experiments were installed on acid soils in different ecoclimatic conditions of the Belgian Ardenne. Soil pH, exchangeable cations and $\mathrm{P}$ contents as well as foliar nutrient concentrations were monitored 1 and 3 years following the application of either (1) $3 \mathrm{tha}^{-1}$ of a dolomitic limestone or (2) $3 \mathrm{tha}^{-1}$ of a dolomitic limestone plus different amounts of $\mathrm{P}(0-800 \mathrm{~kg}$ natural phosphate) and/or $\mathrm{K}\left(0-250 \mathrm{~kg} \mathrm{~K}_{2} \mathrm{SO}_{4}\right)$. Dolomite rapidly increased $\mathrm{Ca}$ and $\mathrm{Mg}$ concentrations in the $0-10 \mathrm{~cm}$ soil layer and in the tree leaves. After three years, exchangeable $\mathrm{Al}$ was significantly lower in the first soil layer but it still represented more than 50\% of the exchangeable cations. Mean $\mathrm{pH}$ increase in the $0-10 \mathrm{~cm}$ layer was less than $0.5 \mathrm{pH}$ units. Dolomite alone tended to reduce mean $\mathrm{K}$ concentrations in the soils and/or leaves of the beech stands. The addition of potassium sulphate to dolomite generally increased the soil and foliar $\mathrm{K}$ contents in the spruce stands contrary to the beech stands. It also tended to increase the resaturation of the exchange complex with $\mathrm{Ca}$ and $\mathrm{Mg}$ ions. The effects of natural phosphate addition were restricted to a slight increase of $\mathrm{P}$ foliar concentrations. The B foliar concentrations were reduced by both treatments, whereas $\mathrm{Zn}$ concentrations increased significantly. The between stands variability of soil and foliage chemical properties was important but did not influence the effects of the treatments.
\end{abstract}

base cation fertilization / micronutrient / Picea abies / Fagus sylvatica

Résumé - Effets à l'échelle régionale de la fertilisation en cations basiques sur des peuplements d'épicéa commun et de hêtre situés sur des sols bruns acides : analyses de sols et feuilles. Dix dispositifs ont été installés dans différentes conditions écoclimatiques de l'Ardenne belge. Les cations échangeables, le $\mathrm{pH}$, la concentration en $\mathrm{P}$ dans le sol et les teneurs foliaires en éléments ont été déterminés 1 et 3 ans après l'application de (1) $3 \mathrm{tha}^{-1}$ de dolomie ou (2) $3 \mathrm{tha}^{-1}$ de dolomie plus différentes doses de $\mathrm{P}(0-800 \mathrm{~kg}$ de phosphates naturels) et/ou de $\mathrm{K}\left(0-250 \mathrm{~kg} \mathrm{~K}_{2} \mathrm{SO}_{4}\right)$. La dolomie permet d'accroître rapidement la concentration en Ca et $\mathrm{Mg}$ dans les dix premiers cm du sol et dans les feuilles. Après 3 ans, l'Al échangeable diminue mais seulement dans la première couche de sol. Dans cette même couche, l'accroissement de $\mathrm{pH}$ est limité à une demi unité. La dolomie seule a tendance à réduire les teneurs en K échangeable dans le sol et les feuilles des arbres en hêtraies. L'application de $\mathrm{K}_{2} \mathrm{SO}_{4}$ permet finalement d'accroître la concentration en $\mathrm{K}$ dans le sol et les feuilles des peuplements d'épicéa. De plus, ce traitement entraîne une plus grande resaturation du complexe d'échange en Ca et Mg. Les phosphates naturels augmentent légèrement les teneurs foliaires en P. Le B dans les feuilles diminue suite aux deux traitements et le Zn augmente significativement. La variabilité des propriétés chimiques des sols et des feuilles est importante entre les dispositifs expérimentaux mais n'influence pas l'effet des traitements.

fertilisation en cations basiques / micronutriments / Picea abies / Fagus sylvatica

* Correspondence and reprints

Tél. 32104725 47; Fax. 32104736 97; e-mail: misson@efor.ucl.ac.be 


\section{INTRODUCTION}

During the 1970s the forest condition deteriorated severely in different parts of Europe and North America. In Belgium, great concern arose after the severe decline of Norway spruce during the winter 1982-1983 [36]. The symptoms of foliage discoloration and loss were the same as observed in West Germany since the mid-1970s. These symptoms were partly attributed to the direct effect of atmospheric pollution that had an important impact in Germany [36]. With the benefit of hindsight, it has been demonstrated that several stress factors could impair forest health and that a complex system of ecological interrelationships had to be taken into account [21].

Since then, different studies have shown that nutritional imbalance was a predisposing factor of forest decline for stands situated on acid soils [12, 39]. The foliar yellowing of Norway spruce associated with forest dieback was identified as a symptom of magnesium deficiency $[9,37]$. It has been postulated that these deficiencies could be reinforced by acid and nitrogen inputs from the atmosphere, which accelerate the processes of soil acidification and cation leaching [35]. In South Belgium, several studies demonstrated that besides the well known cases of low concentrations in phosphorous and calcium, magnesium was also at a critical level in $70 \%$ of the sampled soils [17].

Improving the chemical and biological status of the soil by fertilization is thought to be an efficient tool to prevent forest degradation or restore damaged ecosystems $[1,11]$. Controlled laboratory experiments are suitable for the identification of individual soil processes $[28,29]$ but should be corroborated by field experiments. In order to settle management tools to impede forest decline, diagnostic fertilization trials were installed in several countries during the two last decades $[5,11,14,15$, 20]. Besides this, interpretation of previous experiments was carried out [24, 30, 33]. Generally, these studies lacked regional representativeness since they were based on a small number of experimental stands. As a consequence, it was not always clear if stands in the same region but differing in ecoclimatic conditions or species composition would react similarly to fertilization.

The objectives of this study were (i) to test base cation fertilization on acid soil as a method to prevent forest dieback and/or restore forest health in adult stands, (ii) to assess how different ecoclimatic conditions within a geographically limited region could influence the response of stands, and (iii) to compare the response of two commercially important forest-tree species to fertilization.
One and the same experimental design was applied in a network of spruce (Picea abies (L.) Karst.) and beech (Fagus sylvatica L.) adult stands. Various fertilization treatments were tested on replicated plots. Each twoyear, soil as well as foliar analyses were performed. Crown condition was assessed each year and the floristic composition each four years. This article presents the general methodology of the research programme and the results of soil and foliar analyses obtained one and three years after fertilization. A second paper deals with fertilizer effects on the ground vegetation [22].

\section{MATERIALS AND METHODS}

\subsection{Stand selection and description}

Five monospecific even-aged stands of Norway spruce and European beech were selected throughout the Belgian Ardenne according to several criteria. First, experimental stands had to be located on acid and magnesium poor soils. This was tested by foliar and soil analyses before fertilizer application. Second, soil type (Belgian legend, IRSIA 1:20,000 soil map) and topography had to be homogeneous at the stand level. Third, sampling should take into account the ecoclimatic diversity of the region: for each species, stands were chosen in various Ecological Sectors of the Belgian Ardenne as defined by Onclinkx et al. 1987. Selected characteristics of the experimental stands are listed in table $I$.

The spruce stands were approximately 50 years old while the beech stands were around 100 years old at the beginning of the experiment (1995). The altitude of the stands varies between $380 \mathrm{~m}$ and $560 \mathrm{~m}$. Depending on the ecological sector (table I), the mean annual temperature ranges between $6.5^{\circ} \mathrm{C}$ and $8.0^{\circ} \mathrm{C}$, and total annual precipitation varies between $1030 \mathrm{~mm}$ and $1200 \mathrm{~mm}$ [26]. The soils are classified as $G b b$ (Belgian legend) for all the stands, which means well drained acid brown soils dominated by clay/silt, with a stony load $>5 \%$. Following the FAO classification, the selected stands are on Dystric and Eutric cambisol. Humus type is moder. The natural association of the beech stands is LuzuloFagetum and the sub-association varies between typicum and vaccinietosum (table I) [25]. There is no ground vegetation data for the spruce stands since understorey plants are very scarce.

The range of site indexes (SI), based either on dominant height at 50 (spruce) or 100 (beech) years old 
Table I. Selected characteristics of the experimental stands.

\begin{tabular}{ccccccc}
\hline Stand code & Species & Altitude $(\mathrm{m})$ & Ecological sectors & $\begin{array}{c}\text { Phytosociological } \\
\text { associations }\end{array}$ & SI $^{3}$ & BA $^{4}$ \\
\hline 1S & Norway spruce & 470 & Ardenne centro-orientale & 2.3 & 39.0 \\
2S & Norway spruce & 510 & Haute Ardenne & 3.2 & 37.6 \\
3S & Norway spruce & 560 & Haute Ardenne & 3.8 & 40.2 \\
4S & Norway spruce & 430 & Ardenne méridionale & & 2.4 & 40.9 \\
5S & Norway spruce & 420 & Ardenne méridionale & & 2.8 & 52.8 \\
\hline 6B & European beech & 470 & Ardenne occidentale & LF- deschampsietosum & 1.7 & 20.3 \\
7B & European beech & 420 & Ardenne centro-orientale & LF- vaccinietosum & 1.0 & 21.7 \\
8B & European beech & 380 & Ardenne atlantique & LF-typicum & 1.2 & 23.5 \\
9B & European beech & 400 & Ardenne atlantique & LF - deschampsietosum & 1.2 & 18.4 \\
10B & European beech & 445 & Ardenne méridionale & LF - deschampsietosum & 1.5 & 22.9 \\
\hline
\end{tabular}

${ }^{1}$ according to [26].

2 according to [25]. LF = Luzulo fagetum. No ground vegetation data for the spruce stands.

${ }^{3} \mathrm{SI}=$ Site Index according to [3], [27].

${ }^{4} \mathrm{BA}=$ basal area in $\mathrm{m}^{2}$ per ha (winter 1994-1995).

(table I), reflects the diversity of ecoclimatic conditions or site specificity. Differences in basal area (BA, table I) between stands for a given species (winter 1994-1995) result from different thinning regimes.

\subsection{Fertilization treatments}

Preliminary soil (table II) and foliar (table III) analyses were performed on each experimental stand in 1994. Based on these results, two kinds of treatments (table IV) were specified in addition to a control (no fertilization). The F1 treatment brought $3000 \mathrm{~kg} \mathrm{ha}^{-1}$ of dolomitic limestone $\left(55 \% \mathrm{CaCO}_{3} / 40 \% \mathrm{MgCO}_{3}\right)$ in order to raise the $\mathrm{Mg}$ and $\mathrm{Ca}$ deficiencies observed in most stands; in the $3 \mathrm{~S}$ stand it was limited to $2650 \mathrm{~kg} \mathrm{ha}^{-1}$ due to an error during the field work. The F2 treatment consisted of the standard dolomite application plus varying amounts of $\mathrm{P}$ (as natural phosphate) and/or $\mathrm{K}$ (as $\mathrm{K}_{2} \mathrm{SO}_{4}$ ), depending on the site susceptibility to specific induced deficiencies.

The treatments were applied on $45 \times 45 \mathrm{~m}$ square plots for spruce and $50 \times 50 \mathrm{~m}$ square plots for beech, with a buffer zone of at least $25 \mathrm{~m}$ between plots. Two to 4 replications per treatment were made, depending on the stand (table IV). The fertilizer was applied with a blowing engine towed by a Buurnett forwarder during the winter season 1994-1995.

\subsection{Soil sampling and analyses}

The soil was sampled twice after the treatments were applied, respectively during the winter 1995-1996 (one year after treatment) and during the winter 1997-1998 (three years after treatment). Nine core samples per plot and per soil layer $(0-10 \mathrm{~cm}$ and $10-20 \mathrm{~cm})$ were pooled for soil analysis. They were extracted at the nodes of a $15 \times 15 \mathrm{~m}$ grid settled $2 \mathrm{~m}$ apart at each sampling date in order to avoid extracting previously disturbed soil.

For the chemical analyses, we used the harmonised methods of the International Co-operative Programme on Assessment and Monitoring of Air Pollution Effects on Forest [13]. The soil samples were air-dried at $20{ }^{\circ} \mathrm{C}$ and ground to pass a $2 \mathrm{~mm}$ sieve prior to analysis. The moisture content of air-dried soils was determined on a subsample of $5 \mathrm{~g}$ dried overnight at $105^{\circ} \mathrm{C}$. The $\mathrm{pH}$ $\left(\mathrm{H}_{2} \mathrm{O}\right)$ was measured with an electrode, using a soil: solution ratio of 1:5 (m:v). The exchangeable base cations $(\mathrm{Ca}, \mathrm{Mg}, \mathrm{K})$ were extracted with a $0.1 \mathrm{~m} \mathrm{BaCl}_{2}$ agent, with a soil: solution ratio of 1:10 (m:v). Soil P was extracted by aqua regia agent. Extracted base cations $(\mathrm{Ca}$, $\mathrm{Mg}, \mathrm{K}$ ) and $\mathrm{P}$ were determined by inductively-coupled plasma emission spectrometry. For the 1997 sampling, the exchangeable acid cations $(\mathrm{Al}+\mathrm{H})$ were extracted using a $1 \mathrm{~m} \mathrm{KCl}$ agent with a soil: solution ratio of 1:2.5 (m:v). Al and $\mathrm{H}$ were measured by titration with $0.1 \mathrm{~m} \mathrm{NaOH}$. 
Table II. Soil chemical properties of the stands ${ }^{\mathrm{a}}$ before fertilization (1994) compared to deficiency thresholds $(\mathrm{Ca}, \mathrm{Mg}, \mathrm{K} \mathrm{cmol+} / \mathrm{kg}$; P mg/kg).

\begin{tabular}{|c|c|c|c|c|c|}
\hline Stand code & $\mathrm{Ca}^{1}$ & $\operatorname{Mg}^{1}$ & $\mathrm{~K}^{1}$ & $\mathrm{P}^{2}$ & $\mathrm{pH} \mathrm{H}_{2} \mathrm{O}^{3}$ \\
\hline $1 \mathrm{~S}$ & $0.21 *$ & $0.15 *$ & 0.11 & 52.1 & $4.17 *$ \\
\hline $2 \mathrm{~S}$ & $0.18 *$ & $0.11 *$ & 0.11 & 49.5 & 4.47 \\
\hline $3 \mathrm{~S}$ & $0.30 *$ & 0.18 & 0.19 & 74.3 & $4.03 *$ \\
\hline $4 \mathrm{~S}$ & $0.25 *$ & $0.15 *$ & 0.15 & 57.3 & 4.25 \\
\hline $5 \mathrm{~S}$ & $0.25 *$ & $0.14 *$ & 0.16 & 52.2 & $4.06 *$ \\
\hline $6 \mathrm{~B}$ & $0.21 *$ & $0.18 *$ & 0.19 & 67.8 & $3.97 *$ \\
\hline $7 \mathrm{~B}$ & $0.44 *$ & $0.19 *$ & 0.24 & $57.2 *$ & $3.83 *$ \\
\hline $8 B$ & $0.31 *$ & $0.12 *$ & 0.15 & $42.6 *$ & $3.86 *$ \\
\hline $9 \mathrm{~B}$ & 0.60 & 0.29 & 0.28 & 73.7 & $3.86 *$ \\
\hline $10 \mathrm{~B}$ & $0.22 *$ & $0.19 *$ & 0.17 & 79.8 & 4.33 \\
\hline \multicolumn{6}{|c|}{ Deficiency thresholds for the $0-20 \mathrm{~cm}$ soil layer according to [34], [37] } \\
\hline Norway spruce & $<0.50$ & $<0.16$ & $<0.08$ & $<40$ & $<4.2$ \\
\hline Beech & $<0.50$ & $<0.25$ & $<0.10$ & $<60$ & $<4.2$ \\
\hline
\end{tabular}

${ }^{a}$ Means determined from 18 to 24 samples per stand.

$*<$ deficiency threshold.

${ }^{1}$ Extraction with $0.5 \mathrm{M} \mathrm{NH}_{4}$ Acetate+0.2 M EDTA at $\mathrm{pH}=4.65$. Measured by AAS.

${ }^{2}$ Extraction with citric acid (Dyer method). Measured by colorimetry.

${ }^{3}$ Soil: solution ratio of 1:5 (m:v).

Table III. Foliar nutrient concentrations ${ }^{\mathrm{a}}$ at the stand level ${ }^{\mathrm{b}}$ before fertilization (1994) compared to deficiency thresholds (\% of dry matter).

\begin{tabular}{|c|c|c|c|c|}
\hline Stand code & $\mathrm{Ca}$ & $\mathrm{Mg}$ & $\mathrm{K}$ & $\mathrm{P}$ \\
\hline $1 \mathrm{~S}$ & $0.15 * *$ & $0.08 * *$ & $0.44 *$ & $0.12 *$ \\
\hline $2 \mathrm{~S}$ & $0.11 * *$ & $0.06 * *$ & $0.51 *$ & $0.12 *$ \\
\hline $3 \mathrm{~S}$ & $0.13 * *$ & $0.05 * *$ & $0.50 *$ & $0.10 * *$ \\
\hline $4 \mathrm{~S}$ & $0.13 * *$ & $0.08 *$ & $0.41 *$ & 0.16 \\
\hline $5 \mathrm{~S}$ & $0.15 * *$ & $0.06 * *$ & $0.51 *$ & $0.12 *$ \\
\hline $6 \mathrm{~B}$ & $0.36 * *$ & $0.10 *$ & $0.52 * *$ & $0.16 *$ \\
\hline $7 \mathrm{~B}$ & $0.36 * *$ & $0.06 * *$ & $0.57 *$ & $0.14 *$ \\
\hline $8 \mathrm{~B}$ & $0.56 *$ & $0.06 * *$ & $0.91 *$ & $0.17 *$ \\
\hline 9B & $0.45 * *$ & $0.07 * *$ & $0.71 *$ & $0.11 *$ \\
\hline $10 \mathrm{~B}$ & $0.46 * *$ & $0.13 *$ & $0.60 *$ & $0.19 *$ \\
\hline \multicolumn{5}{|c|}{ Deficiency threshold of nutrient foliar concentrations after [34], [37] } \\
\hline Spruce - deficiency & $<0.20$ & $<0.06$ & $<0.40$ & $<0.10$ \\
\hline Spruce - optimum & $>0.50$ & $>0.11$ & $>0.80$ & $>0.15$ \\
\hline Beech - deficiency & $<0.50$ & $<0.08$ & $<0.55$ & $<0.10$ \\
\hline Beech - optimum & $>0.80$ & $>0.15$ & $>1.00$ & $>0.20$ \\
\hline
\end{tabular}

${ }^{\text {a }}$ Digestion by $\mathrm{HNO}_{3}$; determination by ICP.

${ }^{\mathrm{b}}$ Means from 7 to 15 trees per stand (Norway spruce: 1-year-old needles).

$* *<$ deficiency threshold. * Values between deficiency and optimum thresholds. 
Table IV. Applied treatments and experimental design $\left(\mathrm{kg} \mathrm{ha}^{-1}\right)$.

\begin{tabular}{|c|c|c|c|c|c|}
\hline Stand Code & Treatment & Number of Plots & Dolomite Lime $^{1}$ & Natural Phosphate ${ }^{2}$ & Potassium Sulphate $^{3}$ \\
\hline \multirow[t]{3}{*}{$1 \mathrm{~S}$} & Control & 4 & & & \\
\hline & $\mathrm{F} 1$ & 3 & 3000 & & \\
\hline & F2 & 2 & 3000 & 800 & 200 \\
\hline \multirow[t]{3}{*}{$2 \mathrm{~S}$} & Control & 4 & & & \\
\hline & $\mathrm{F} 1$ & 4 & 3000 & & \\
\hline & F2 & 4 & 3000 & 400 & 200 \\
\hline \multirow[t]{3}{*}{$3 \mathrm{~S}$} & Control & 3 & & & \\
\hline & F1 & 3 & 2650 & & \\
\hline & F2 & 3 & 2650 & 350 & \\
\hline \multirow[t]{3}{*}{$4 \mathrm{~S}$} & Control & 3 & & & \\
\hline & $\mathrm{F} 1$ & 3 & 3000 & & \\
\hline & F2 & 3 & 3000 & 400 & 200 \\
\hline \multirow[t]{3}{*}{$5 \mathrm{~S}$} & Control & 3 & & & \\
\hline & $\mathrm{F} 1$ & 3 & 3000 & & \\
\hline & F2 & 3 & 3000 & 400 & 200 \\
\hline \multirow[t]{3}{*}{$6 \mathrm{~B}$} & Control & 3 & & & \\
\hline & $\mathrm{F} 1$ & 3 & 3000 & & \\
\hline & F2 & 3 & 3000 & 400 & 200 \\
\hline \multirow[t]{3}{*}{$7 \mathrm{~B}$} & Control & 3 & & & \\
\hline & $\mathrm{F} 1$ & 3 & 3000 & & \\
\hline & F2 & 3 & 3000 & 400 & 200 \\
\hline \multirow[t]{4}{*}{$8 \mathrm{~B}^{\mathrm{a}}$} & Control & 3 & & & \\
\hline & F1 & 3 & 3000 & & \\
\hline & $\mathrm{F} 2$ & 2 & 3000 & 800 & \\
\hline & F2' & 1 & 3000 & 400 & 250 \\
\hline \multirow[t]{3}{*}{$9 B$} & Control & 3 & & & \\
\hline & F1 & 3 & 3000 & & \\
\hline & F2 & 3 & 3000 & 400 & 200 \\
\hline \multirow[t]{3}{*}{ 10B } & Control & 3 & & & \\
\hline & F1 & 3 & 3000 & & \\
\hline & $\mathrm{F} 2$ & 3 & 3000 & & 200 \\
\hline
\end{tabular}

${ }^{1} \mathrm{CaMg}\left(\mathrm{CO}_{3}\right)_{2}\left(55 \% \mathrm{Ca} \mathrm{CO}_{3}\right.$ and $\left.40 \% \mathrm{Mg} \mathrm{CO}_{3}\right)$ of particle size $<100 \mu \mathrm{m}$.

${ }^{2} 31 \%$ of $\mathrm{P}_{2} \mathrm{O}_{5}$ in powder.

${ }^{3} 50 \%$ of $\mathrm{K}_{2} \mathrm{O}$ in powder.

' $\mathrm{F} 2$ and F2' were combined for the statistical analyses.

\subsection{Foliar sampling and analyses}

The tree leaves were sampled by shooting in the upper third of the crowns one and three years after treatment application. They were collected from the same 4 or 8 dominant and permanently marked beech- or spruce-trees per plot, respectively. The leaves were sampled during the second part of August for beech, and in winter for spruce; for the latter species, 1- and 2-year old needles were separated. One composite sample per plot and per needle age (spruce) was analysed.
Analyses were made according to the harmonised procedures of the International Co-operative Programme on Assessment and Monitoring of Air Pollution Effects on Forest [13]. Each composite sample was oven-dried at $65{ }^{\circ} \mathrm{C}$ during three days and ground to pass a $0.2 \mathrm{~mm}$ sieve prior to analysis. For the digestion, we used the dryashing procedure at $450{ }^{\circ} \mathrm{C}$ during 4 hours. Digests were made soluble in $\mathrm{HCl}$ solution. Element concentrations were determined by inductively-coupled plasma emission spectrometry for $\mathrm{Ca}, \mathrm{Mg}, \mathrm{K}, \mathrm{P}, \mathrm{Al}, \mathrm{B}, \mathrm{Cu}, \mathrm{Fe}, \mathrm{Na}$, and $\mathrm{Zn}$. Total $\mathrm{N}$ was determined by the Kjeldahl procedure. 


\subsection{Statistical analyses}

Differences between treatments and stands for a given species and sampling date were tested with a two-way ANOVA, including the interaction term. We then performed Dunnett's two-tailed $t$ tests on least square means, to test for any difference between treatments and the control for all main effects. We used the SAS statistical package for all calculations (GLM procedure with LSMEANS statement) [31].

\section{RESULTS AND DISCUSSION}

\subsection{Soils}

Dolomite lime, either alone (F1) or combined with others products (F2), had a rapid effect on the exchangeable $\mathrm{Ca}-\mathrm{Mg}$ content of the topsoil layer $(0-10 \mathrm{~cm})$ (table $V$ ). The mean concentrations of both elements were significantly higher in the F1 and F2 treatments compared to the CONTROL already one year after fertilizer application (table VI). The difference in $\mathrm{Ca}$ and $\mathrm{Mg}$

Table V. Values of $p$ (F > F obs) from Anova 2 calculated on the soil data.

\begin{tabular}{|c|c|c|c|c|c|c|c|c|c|c|c|}
\hline Soil layer & Species & Year & Effect $^{1}$ & $\mathrm{Df}^{2}$ & $\mathrm{Ca}$ & $\mathrm{Mg}$ & $\mathrm{K}$ & $\mathrm{Al}$ & $\mathrm{H}$ & $\mathrm{P}$ & $\mathrm{pH} \mathrm{H} \mathrm{H}_{2} \mathrm{O}$ \\
\hline \multirow[t]{12}{*}{$0-10 \mathrm{~cm}$} & Spruce & 1995 & $\mathrm{~T}$ & 2 & $<0.001^{\mathrm{b}}$ & $<0.001^{\mathrm{b}}$ & $<0.001^{\mathrm{b}}$ & ND & ND & 0.453 & 0.141 \\
\hline & & & S & 4 & $0.003^{\mathrm{b}}$ & $0.002^{\mathrm{b}}$ & $0.015^{\mathrm{a}}$ & ND & ND & 0.994 & $<0.001^{\mathrm{b}}$ \\
\hline & & & $\mathrm{T} \times \mathrm{S}$ & 8 & 0.156 & $0.012^{\mathrm{a}}$ & 0.061 & ND & ND & 0.227 & 0.192 \\
\hline & & 1997 & $\mathrm{~T}$ & 2 & $<0.001^{\mathrm{b}}$ & $<0.001^{\mathrm{b}}$ & $0.009^{b}$ & $0.002^{b}$ & 0.066 & 0.126 & $<0.001^{\mathrm{b}}$ \\
\hline & & & $\mathrm{S}$ & 4 & $0.002^{\mathrm{b}}$ & $0.029^{\mathrm{a}}$ & 0.685 & $<0.001^{\mathrm{b}}$ & $<0.001^{\mathrm{b}}$ & $<0.004^{\mathrm{b}}$ & $<0.001^{\mathrm{b}}$ \\
\hline & & & $\mathrm{T} \times \mathrm{S}$ & 8 & 0.202 & 0.181 & 0.766 & 0.428 & 0.146 & 0.490 & 0.093 \\
\hline & Beech & 1995 & $\mathrm{~T}$ & 2 & $0.005^{\mathrm{b}}$ & $<0.001^{\mathrm{b}}$ & 0.117 & ND & ND & 0.998 & 0.055 \\
\hline & & & $\mathrm{S}$ & 4 & $<0.001^{\mathrm{b}}$ & $<0.001^{\mathrm{b}}$ & $0.007^{\mathrm{b}}$ & ND & ND & $<0.001^{\mathrm{b}}$ & 0.148 \\
\hline & & & $\mathrm{T} \times \mathrm{S}$ & 8 & 0.105 & $0.001^{\mathrm{b}}$ & 0.090 & ND & ND & $0.019^{\mathrm{a}}$ & 0.463 \\
\hline & & 1997 & $\mathrm{~T}$ & 2 & $<0.001^{\mathrm{b}}$ & $<0.001^{b}$ & $0.019^{\mathrm{a}}$ & $<0.001^{\mathrm{b}}$ & $<0.001^{\mathrm{b}}$ & 0.541 & $<0.001^{\mathrm{b}}$ \\
\hline & & & S & 4 & $0.012^{\mathrm{a}}$ & 0.076 & $<0.001^{\mathrm{b}}$ & $<0.001^{\mathrm{b}}$ & 0.880 & $<0.001^{\mathrm{b}}$ & 0.071 \\
\hline & & & $\mathrm{T} \times \mathrm{S}$ & 8 & 0.167 & 0.169 & 0.904 & $0.022^{\mathrm{a}}$ & 0.133 & 0.417 & 0.118 \\
\hline \multirow[t]{12}{*}{$10-20 \mathrm{~cm}$} & Spruce & 1995 & $\mathrm{~T}$ & 2 & 0.184 & $0.001^{\mathrm{b}}$ & $0.017^{\mathrm{a}}$ & ND & ND & 0.706 & 0.678 \\
\hline & & & $\mathrm{S}$ & 4 & $0.001^{\mathrm{b}}$ & $0.001^{\mathrm{b}}$ & 0.129 & ND & ND & 0.592 & $0.007^{\mathrm{b}}$ \\
\hline & & & $\mathrm{T} \times \mathrm{S}$ & 8 & 0.142 & $0.004^{\mathrm{b}}$ & 0.093 & $\mathrm{ND}$ & ND & 0.316 & 0.068 \\
\hline & & 1997 & $\mathrm{~T}$ & 2 & $<0.001^{\mathrm{b}}$ & $<0.001^{b}$ & $0.001^{\mathrm{b}}$ & 0.502 & 0.339 & $0.016^{\mathrm{a}}$ & $<0.001^{\mathrm{b}}$ \\
\hline & & & $\mathrm{S}$ & 4 & $0.006^{b}$ & $<0.001^{b}$ & $0.012^{\mathrm{a}}$ & $<0.001^{b}$ & $0.031^{\mathrm{a}}$ & $0.013^{\mathrm{a}}$ & $<0.001^{\mathrm{b}}$ \\
\hline & & & $\mathrm{T} \times \mathrm{S}$ & 8 & 0.111 & $0.039^{\mathrm{a}}$ & 0.126 & 0.407 & 0.470 & 0.077 & 0.052 \\
\hline & Beech & 1995 & $\mathrm{~T}$ & 2 & 0.899 & 0.716 & 0.054 & $\mathrm{ND}$ & $\mathrm{ND}$ & 0.769 & 0.436 \\
\hline & & & $\mathrm{S}$ & 4 & 0.188 & 0.573 & 0.283 & ND & ND & $<0.001^{\mathrm{b}}$ & 0.393 \\
\hline & & & $\mathrm{T} \times \mathrm{S}$ & 8 & 0.633 & 0.622 & 0.803 & ND & ND & 0.006 & 0.120 \\
\hline & & 1997 & $\mathrm{~T}$ & 2 & 0.199 & 0.108 & 0.474 & 0.201 & 0.548 & 0.474 & 0.155 \\
\hline & & & $\mathrm{S}$ & 4 & 0.121 & 0.475 & $<0.001^{\mathrm{b}}$ & 0.400 & 0.367 & $<0.001^{\mathrm{b}}$ & 0.521 \\
\hline & & & $\mathrm{T} \times \mathrm{S}$ & 8 & 0.355 & 0.249 & 0.731 & 0.135 & 0.481 & 0.256 & 0.199 \\
\hline
\end{tabular}

${ }^{1} \mathrm{~T}=$ TREATMENT $; \mathrm{S}=\mathrm{STAND} ; \mathrm{T} \times \mathrm{S}=\mathrm{TREATMENT} \times \mathrm{STAND}$ interaction.

${ }^{2}$ Df: degree of freedom.

${ }^{\mathrm{a}} 0.01<p \leq 0.05 ;{ }^{\mathrm{b}} p \leq 0.01$

$\mathrm{ND}=$ no data. 
Table VI. Means and coefficient of variation (CV\%) of the soil chemical properties by soil layer, species, year and treatment. (Ca, $\mathrm{Mg}$, $\mathrm{K}, \mathrm{Al}, \mathrm{H}$ in $\mathrm{cmol}+\mathrm{kg}$; $\mathrm{P}$ in $\mathrm{mg} / \mathrm{kg}$ ).

\begin{tabular}{|c|c|c|c|c|c|c|c|c|c|c|c|c|c|c|c|c|c|}
\hline \multirow[t]{2}{*}{ Layer } & \multirow[t]{2}{*}{ Species } & \multirow[t]{2}{*}{ Year } & \multirow[t]{2}{*}{ Treatment } & \multirow[t]{2}{*}{$\mathrm{Ca}$} & \multirow[b]{2}{*}{$\mathrm{CV}$} & \multirow[t]{2}{*}{$\mathrm{Mg}$} & \multirow{2}{*}{\multicolumn{2}{|c|}{ K }} & \multirow[b]{2}{*}{$\mathrm{CV}$} & \multirow[t]{2}{*}{$\mathrm{Al}$} & \multirow{2}{*}{\multicolumn{2}{|c|}{$\mathrm{H}$}} & \multirow[b]{2}{*}{$\mathrm{CV}$} & \multirow[t]{2}{*}{$\mathrm{P}$} & \multirow{2}{*}{\multicolumn{2}{|c|}{$\mathrm{pH} \mathrm{H}_{2} \mathrm{O}$}} & \multirow[b]{2}{*}{$\mathrm{CV}$} \\
\hline & & & & & & & & & & & & & & & & & \\
\hline \multirow[t]{12}{*}{$0-10 \mathrm{~cm}$} & Spruce & 1995 & Control & 0.19 & 22 & 0.13 & 17 & 0.10 & 8 & ND & ND & ND & ND & 715.1 & 5 & 4.35 & 1 \\
\hline & & & $\mathrm{F} 1$ & $0.41^{*}$ & 10 & $0.32^{*}$ & 7 & 0.09 & 9 & ND & ND & ND & ND & 747.0 & 5 & 4.38 & 1 \\
\hline & & & $\mathrm{F} 2$ & $0.42 *$ & 10 & $0.35^{*}$ & 7 & $0.15^{*}$ & 6 & ND & ND & ND & $\mathrm{ND}$ & 776.6 & 5 & 4.42 & 1 \\
\hline & & 1997 & Control & 0.21 & 65 & 0.16 & 62 & 0.11 & 6 & 5.75 & 3 & 1.09 & 4 & 786.9 & 5 & 4.17 & 1 \\
\hline & & & $\mathrm{F} 1$ & $1.08 *$ & 13 & $0.92^{*}$ & 11 & 0.11 & 6 & 5.40 & 4 & 0.99 & 5 & 818.9 & 5 & $4.45^{*}$ & 1 \\
\hline & & & $\mathrm{F} 2$ & $1.40^{*}$ & 11 & $1.14^{*}$ & 9 & 0.13 & 5 & $4.71^{*}$ & 4 & $0.92^{*}$ & 6 & 901.2 & 5 & $4.53^{*}$ & 1 \\
\hline & Beech & 1995 & Control & 0.29 & 25 & 0.15 & 23 & 0.1 & 8 & ND & ND & $\mathrm{ND}$ & ND & 616.5 & 3 & 4.32 & 1 \\
\hline & & & $\mathrm{F} 1$ & $0.64^{*}$ & 11 & $0.37^{*}$ & 9 & 0.12 & 8 & ND & ND & ND & ND & 614.7 & 3 & 4.46 & 1 \\
\hline & & & $\mathrm{F} 2$ & $0.55^{*}$ & 14 & $0.40^{*}$ & 9 & 0.14 & 7 & ND & ND & ND & ND & 615.4 & 3 & 4.39 & 1 \\
\hline & & 1997 & Control & 0.44 & 42 & 0.25 & 55 & 0.15 & 5 & 5.89 & 3 & 1.47 & 6 & 808.8 & 3 & 4.05 & 1 \\
\hline & & & $\mathrm{F} 1$ & $1.50^{*}$ & 12 & $1.06^{*}$ & 13 & $0.12^{*}$ & 7 & $4.64^{*}$ & 4 & $0.85^{*}$ & 10 & 794.0 & 3 & $4.46^{*}$ & 1 \\
\hline & & & $\mathrm{F} 2$ & $1.59^{*}$ & 12 & $1.19^{*}$ & 12 & $0.13^{*}$ & 7 & $4.68 *$ & 4 & $1.06^{*}$ & 9 & 836.0 & 3 & $4.37^{*}$ & 1 \\
\hline \multirow[t]{12}{*}{$10-20 \mathrm{~cm}$} & Spruce & 1995 & Control & 0.12 & 17 & 0.07 & 17 & 0.06 & 10 & ND & ND & ND & ND & 698.4 & 5 & 4.51 & 0 \\
\hline & & & $\mathrm{F} 1$ & 0.16 & 13 & $0.13^{*}$ & 9 & 0.06 & 10 & ND & ND & ND & ND & 709.7 & 5 & 4.54 & 0 \\
\hline & & & $\mathrm{F} 2$ & 0.17 & 13 & $0.13^{*}$ & 10 & $0.08^{*}$ & 7 & ND & ND & ND & ND & 739.1 & 5 & 4.53 & 1 \\
\hline & & 1997 & Control & 0.08 & 28 & 0.06 & 24 & 0.05 & 6 & 3.72 & 4 & 0.54 & 9 & 761.5 & 8 & 4.42 & 0 \\
\hline & & & $\mathrm{F} 1$ & $0.20 *$ & 11 & $0.20 *$ & 8 & 0.05 & 6 & 3.79 & 4 & 0.48 & 10 & 776.6 & 8 & $4.52^{*}$ & 0 \\
\hline & & & $\mathrm{F} 2$ & $0.22 *$ & 11 & $0.21^{*}$ & 8 & 0.07 & 5 & 3.56 & 4 & 0.44 & 11 & 1015.0 & 7 & $4.55^{*}$ & 0 \\
\hline & Beech & 1995 & Control & 0.26 & 31 & 0.11 & 22 & 0.07 & 11 & ND & ND & ND & ND & 562.3 & 3 & 4.55 & 1 \\
\hline & & & $\mathrm{F} 1$ & 0.21 & 38 & 0.13 & 19 & 0.07 & 11 & ND & ND & ND & ND & 578.6 & 3 & 4.60 & 1 \\
\hline & & & $\mathrm{F} 2$ & 0.22 & 39 & 0.14 & 18 & 0.10 & 9 & ND & ND & ND & ND & 567.0 & 3 & 4.54 & 1 \\
\hline & & 1997 & Control & 0.14 & 67 & 0.10 & 53 & 0.06 & 8 & 4.55 & 5 & 0.48 & 50 & 722.5 & 3 & 4.44 & 1 \\
\hline & & & F1 & 0.26 & 36 & 0.19 & 29 & 0.05 & 10 & 4.15 & 6 & 0.83 & 29 & 712.4 & 3 & 4.55 & 1 \\
\hline & & & $\mathrm{F} 2$ & 0.39 & 25 & 0.28 & 21 & 0.06 & 10 & 3.95 & 6 & 0.54 & 44 & 750.5 & 3 & 4.54 & 1 \\
\hline
\end{tabular}

* Significant difference compared to the control (Dunnett's test, $\alpha$ level $=5 \%$ ).

$\mathrm{ND}=$ no data .

concentrations between fertilized and control plots further increased in 1997: mean Ca-Mg concentrations were 3 to 7 times higher in the $\mathrm{F} 1$ and $\mathrm{F} 2$ treatments than in the CONTROL (table VI). Considering mean concentrations, there was no evidence for differences between the migration of $\mathrm{Ca}$ and $\mathrm{Mg}$ at this depth.

These results are consistent with those of Dulière et al. (1999) who reported a 3 to 9 fold increase in $\mathrm{Ca}$ and $\mathrm{Mg}$ concentrations in the $0-10 \mathrm{~cm}$ soil layer 6 months after a $5 \mathrm{t} \mathrm{ha}^{-1}$ dolomite application, compared to the control.
An important part of $\mathrm{Ca}$ and $\mathrm{Mg}$ is however likely to remain within the holorganic horizons [28, 30]. At a larger time scale, liming has been reported to have a positive effect on humus mineralization, with increased cation mobilization and migration down to the mineral layers [16].

At larger depth, dolomite lime influenced exchangeable $\mathrm{Ca}$ and $\mathrm{Mg}$ of the 10-20 cm layer more quickly under spruce than under beech. In 1997 for example, the TREATMENT effect was significant for both elements for spruce, but not for beech (table V). Closer examination 
of the data, however, showed comparable $\mathrm{Ca}$ and $\mathrm{Mg}$ increase for both species (table VI). This apparent difference in TREATMENT effects was therefore probably due to the greater variability of exchangeable cation contents in the beech compared to the spruce stands, as illustrated by the respective coefficients of variation.

In the surface layer, dolomite had a negative effect on exchangeable $\mathrm{K}$ concentration in the soil of the beech stands as indicated by the small but significant decrease in mean $\mathrm{K}$ concentrations in the F1 treatment in 1997 (table VI). The addition of potassium sulphate (F2 treatment) was apparently not sufficient to maintain $\mathrm{K}$ concentrations at levels similar to those of the control (table VI, 1997). Such decrease probably resulted from the displacement of resident $\mathrm{K}$ by $\mathrm{Ca}[2,30]$. By contrast, dolomite did not decrease exchangeable $\mathrm{K}$ contents at the
$0-10 \mathrm{~cm}$ level in the spruce stands, whatever the period (tables $V$ and $V I$ ). Furthermore, the addition of potassium sulphate significantly increased the K concentrations of this layer in 1995 (table VI). In the 10-20 cm layer, the TREATMENT effect on soil $\mathrm{K}$ concentrations was limited to the spruce stands (table $V$ ). More detailed studies would be necessary to understand the difference of soil response between beech and spruce stands.

For all species and soil depths, $\mathrm{P}$ concentrations did not show any significant change following the application of natural phosphate (tables $V$ and VI, F2 treatments). Two main reasons could account for this observation: phosphorous retention in the organic layer and/or change in phosphorous concentrations insufficient to be detected by the extraction method used in this study.

\section{a) $0-10 \mathrm{~cm}$}

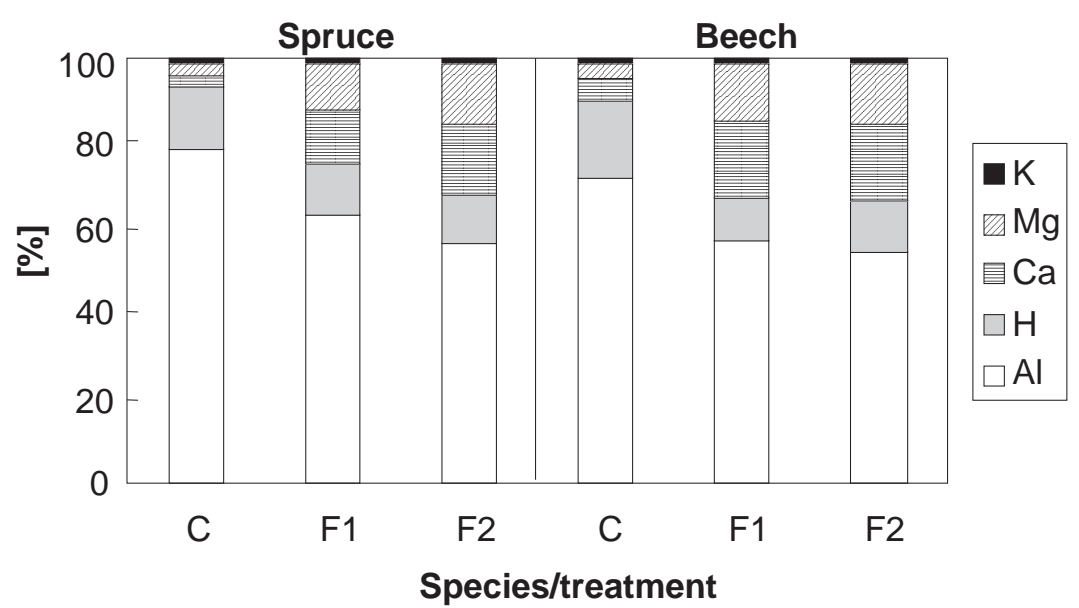

b) $10-20 \mathrm{~cm}$

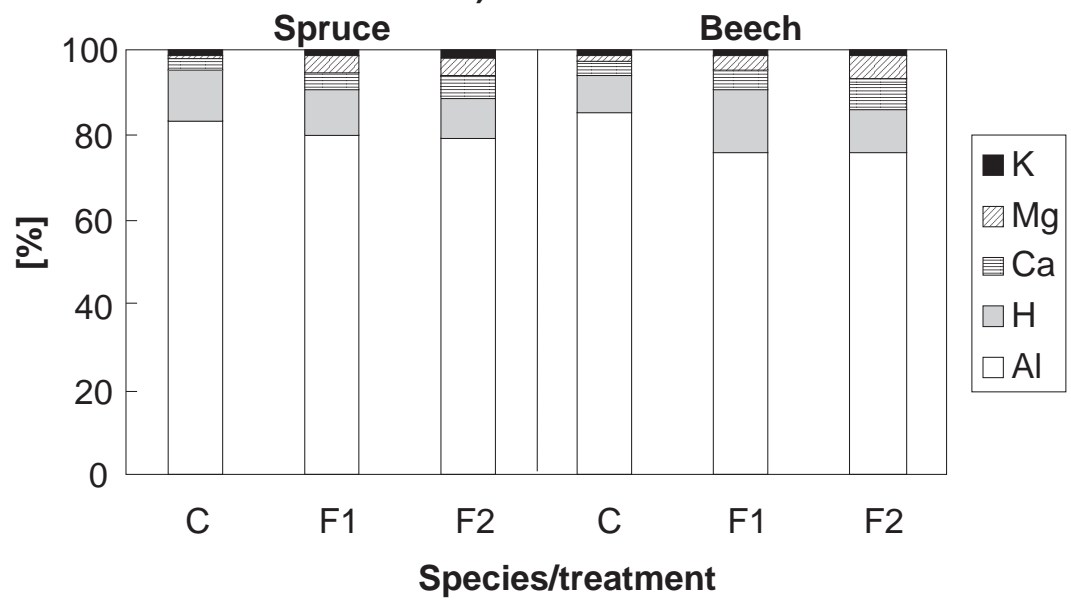

Figure $1(\mathbf{a}, \mathbf{b})$. Mean proportions of cations on the exchangeable complex (exch. cations/ECEC and $\mathrm{ECEC}=\sum \mathrm{Ca}, \mathrm{Mg}, \mathrm{K}, \mathrm{Al}$, $\mathrm{H})$ in the $0-10$ and $10-20 \mathrm{~cm}$ soil layers of each treatment (1997). (C: CONTROL; F1: Dolomite Lime; F2: Dolomite Lime + Natural Phosphate + Potassium Sulphate). 
Three years after fertilizer application, the TREATMENT effect was significant in the $0-10 \mathrm{~cm}$ layer for $\mathrm{pH}, \mathrm{Al}$ (spruce, beech) and $\mathrm{H}$ (beech) (table $\mathrm{V}$ ). In the F1 and F2 treatments $(0-10 \mathrm{~cm})$, the increase of exchangeable $(\mathrm{Ca}+\mathrm{Mg})$ following dolomite application was balanced by the decrease of exchangeable $(\mathrm{Al}+\mathrm{H})$ in the beech stands, whereas it was associated with a limited ECEC increase $\left(\cong 1 \mathrm{cmol}+\mathrm{kg}^{-1}\right)$ in the spruce stands. Depending on factors such as the organic carbon content of the soil and the amount of applied alkalinity, exchangeable $\mathrm{Al}$ and $\mathrm{H}$ in the mineral soil may be neutralised without important change of the dissociated charge [19, 23, 30].

At deeper soil layers, there was no significant TREATMENT effect for $\mathrm{Al}$ or $\mathrm{H}$, for any species (table $\mathrm{V}$ ). The rise in $\mathrm{pH}$ following fertilization was limited to the spruce stands in 1997, and mean $\mathrm{pH}$ in the F1 and F2 treatments differed from the control by only one tenth of $\mathrm{pH}$ unit (tables $V$ and $V I$ ).

Despite the decrease of exchangeable Al following base cation fertilization, Al still remained largely dominant on the ECEC of both layers. For instance, exchangeable Al still accounted for $57 \%$ (spruce) and 54\% (beech) of the ECEC in the $0-10 \mathrm{~cm}$ layer of the F2-treated plots (figure 1a). The proportion of $\mathrm{Al}$ was still higher in the $10-20 \mathrm{~cm}$ soil layer, being around $80 \%$ and $75 \%$ for the spruce and beech stands, respectively (figure $1 b$ ).

The overall limited downward migration of base cations and alkalinity through the soil profiles in the short term can be attributed to the kinetics of dissolution of the amendments and to the formation of exchangeable sites in the holorganic horizons, as shown by different studies $[23,29,30]$. At longer time scale, however, the rate of humus mineralization would probably increase in the fertilized plots and this re-acidification would favour the supply of cations to deeper mineral horizons [16].

From figure $1 a$ it can be seen that the proportional decrease of the acid cations $(\mathrm{Al}+\mathrm{H})$ was more important when complete base cation fertilization (F2) was applied instead of dolomite alone (F1), despite comparable $\mathrm{Ca}$ and $\mathrm{Mg}$ application. This can be explained by the migration of part of $\mathrm{Ca}$ and $\mathrm{Mg}$ ions with the mobile $\mathrm{SO}_{4}{ }^{2-}$ anions originating from the potassium sulphate fertilizer $[28,29]$. On the other hand, several authors observed considerable changes in the decomposers population after $\mathrm{P}$ and/or $\mathrm{K}$ fertilization [7, 32]. This phenomenon could also contribute to the increased release of $\mathrm{Ca}$ and $\mathrm{Mg}$ cations [38].

A significant STAND effect was detected for most soil variables, for spruce as well as for beech $(0-10 \mathrm{~cm})$ (table $V$ ). The factors acting locally, such as local climate or stand history, all have a potential influence on the soil chemical properties of the stands. Nevertheless, the limited number of TREATMENT $\times$ STAND interactions indicates that in most cases the different stands reacted similarly to fertilization, showing comparable trends (tables $V$ and $V I$ ). Thus, even if the ecoclimatic conditions as well as the initial soil chemical properties were heterogeneous between stands, the forcing effects of the treatments were strong enough to account for the similarities of response.

\subsection{Trees}

The response of trees to fertilization was particularly rapid for $\mathrm{Ca}$ whatever the species since the TREATMENT effect was already significant during the vegetation period just following fertilization (1995) (table VII). For $\mathrm{Mg}$, the difference between treatments was not significant until 1997 (table VII). In addition, the increase of foliar $\mathrm{Ca}$ after fertilization was proportionally more important than that of $\mathrm{Mg}$ (table VIII, 1997 data), despite comparable soil evolution (table VI).

In some cases, the mean foliar concentrations of $\mathrm{Ca}$ and/or Mg exceeded the deficiency threshold following application of the fertilizers. In the beech stands for example, Ca concentrations reached $0.43 \%$ (CONTROL), $0.55 \%(\mathrm{~F} 1)$ and $0.52 \%(\mathrm{~F} 2)$ in 1995 , the last two values being higher than the deficiency threshold $(0.50 \%)$ (tables III and VIII). Nevertheless, inter-annual variability of foliar concentrations was important, as also shown in other studies [18]. It is interesting to see that for both elements mean foliar concentrations were relatively similar between treatments, whatever the species (table VIII).

Addition of dolomite alone tended to decrease slightly (Dunnett's test not significant) the mean K foliar concentrations in the beech stands, compared to the control. This could be due to an increased $\mathrm{Ca}-\mathrm{K}$ absorption antagonism at the plant level resulting from the relative increase of exchangeable $\mathrm{Ca}$ in the soil. This suggests a risk of induced-K deficiency following liming in case of low initial $\mathrm{K}$ concentrations in the soil $[2,4,10,33]$. The simultaneous application of potassium sulphate with dolomite (F2 treatment) tended to raise the K foliar concentrations for both species, in comparison to the CONTROL (table VIII). The Dunnett's test was however only significant in the spruce stands (table VIII).

Even if the $\mathrm{P}$ concentration at the soil level was not significantly improved by natural phosphate addition (F2 treatment), the foliar concentration increased 
Table VII. Values of $p$ (F > F obs) from Anova 2 calculated on foliar analysis data.

\begin{tabular}{|c|c|c|c|c|c|c|c|c|c|c|c|c|c|c|c|}
\hline Species & Year & $\begin{array}{l}\text { Age of } \\
\text { needles }\end{array}$ & Effect $^{1}$ & $\mathrm{Df}^{2}$ & $\mathrm{Ca}$ & $\mathrm{Mg}$ & $\mathrm{K}$ & $\mathrm{P}$ & $\mathrm{Al}$ & B & $\mathrm{Cu}$ & $\mathrm{Fe}$ & $\mathrm{Na}$ & $\mathrm{Zn}$ & $\mathrm{N}$ \\
\hline \multirow[t]{12}{*}{ Spruce } & 1995 & 1 & $\mathrm{~T}$ & 2 & $0.030^{\mathrm{a}}$ & 0.739 & $0.026^{\mathrm{a}}$ & 0.089 & 0.841 & 0.642 & ND & 0.237 & ND & $0.008^{b}$ & 0.136 \\
\hline & & & S & 4 & $0.001^{\mathrm{b}}$ & $0.001^{b}$ & $0.002^{\mathrm{b}}$ & 0.059 & $0.001^{\mathrm{b}}$ & $0.001^{b}$ & ND & $0.003^{b}$ & ND & $0.001^{b}$ & 0.681 \\
\hline & & & $\mathrm{T} \times \mathrm{S}$ & 8 & 0.841 & 0.205 & 0.578 & 0.567 & 0.955 & 0.641 & ND & 0.101 & ND & 0.609 & 0.288 \\
\hline & & 2 & $\mathrm{~T}$ & 2 & 0.107 & 0.771 & $0.004^{\mathrm{b}}$ & $0.001^{b}$ & 0.432 & 0.686 & ND & 0.887 & ND & $0.002^{b}$ & ND \\
\hline & & & S & 4 & $0.001^{\mathrm{b}}$ & $0.001^{b}$ & $0.019^{\mathrm{a}}$ & $0.001^{\mathrm{b}}$ & $0.001^{b}$ & $0.014^{b}$ & ND & $0.023^{\mathrm{a}}$ & ND & $0.001^{\mathrm{b}}$ & ND \\
\hline & & & $\mathrm{T} \times \mathrm{S}$ & 8 & 0.800 & 0.147 & 0.188 & 0.060 & 0.785 & 0.862 & ND & 0.865 & ND & 0.755 & ND \\
\hline & 1997 & 1 & $\mathrm{~T}$ & 2 & $0.001^{\mathrm{b}}$ & $0.001^{\mathrm{b}}$ & $0.002^{\mathrm{b}}$ & $0.001^{b}$ & $0.002^{\mathrm{b}}$ & $0.001^{\mathrm{b}}$ & $0.036^{\mathrm{a}}$ & 0.286 & $0.002^{b}$ & $0.001^{b}$ & 0.856 \\
\hline & & & S & 4 & $0.003^{b}$ & $0.001^{b}$ & $0.001^{\mathrm{b}}$ & $0.001^{b}$ & $0.001^{b}$ & $0.001^{b}$ & $0.001^{b}$ & $0.001^{\mathrm{b}}$ & $0.001^{\mathrm{b}}$ & $0.001^{b}$ & $0.001^{\mathrm{b}}$ \\
\hline & & & $\mathrm{T} \times \mathrm{S}$ & 8 & 0.252 & 0.964 & $0.003^{\mathrm{b}}$ & 0.153 & 0.063 & 0.674 & 0.153 & 0.920 & 0.399 & 0.775 & 0.180 \\
\hline & & 2 & $\mathrm{~T}$ & 2 & $0.001^{\mathrm{b}}$ & $0.001^{\mathrm{b}}$ & 0.169 & $0.001^{b}$ & $0.001^{b}$ & $0.001^{b}$ & 0.061 & $0.032^{\mathrm{a}}$ & $0.045^{\mathrm{a}}$ & $0.001^{b}$ & 0.795 \\
\hline & & & S & 4 & 0.201 & $0.001^{\mathrm{b}}$ & 0.257 & $0.004^{b}$ & $0.001^{b}$ & $0.001^{\mathrm{b}}$ & $0.002^{\mathrm{b}}$ & $0.001^{b}$ & $0.001^{b}$ & $0.005^{b}$ & $0.001^{\mathrm{b}}$ \\
\hline & & & $\mathrm{T} \times \mathrm{S}$ & 8 & 0.863 & 0.344 & 0.062 & 0.136 & 0.087 & 0.725 & 0.973 & $0.008^{b}$ & 0.246 & 0.366 & 0.332 \\
\hline \multirow[t]{6}{*}{ Beech } & 1995 & & $\mathrm{~T}$ & 2 & $0.004^{b}$ & 0.327 & $0.048^{\mathrm{a}}$ & 0.067 & 0.131 & $0.001^{\mathrm{b}}$ & $0.002^{\mathrm{b}}$ & 0.206 & $0.021^{\mathrm{a}}$ & 0.089 & 0.207 \\
\hline & & & $\mathrm{S}$ & 4 & $0.001^{b}$ & $0.001^{b}$ & $0.001^{\mathrm{b}}$ & $0.008^{b}$ & $0.001^{b}$ & $0.001^{b}$ & $0.007^{\mathrm{b}}$ & 0.071 & $0.001^{\mathrm{b}}$ & 0.521 & $0.003^{\mathrm{b}}$ \\
\hline & & & $\mathrm{T} \times \mathrm{S}$ & 8 & 0.350 & 0.431 & 0.347 & 0.556 & 0.420 & 0.252 & 0.144 & 0.524 & 0.262 & 0.636 & 0.856 \\
\hline & 1997 & & $\mathrm{~T}$ & 2 & $0.001^{\mathrm{b}}$ & $0.009^{b}$ & 0.464 & $0.037^{\mathrm{a}}$ & 0.129 & $0.001^{b}$ & 0.981 & 0.311 & 0.733 & $0.001^{b}$ & 0.240 \\
\hline & & & $\mathrm{S}$ & 4 & $0.017^{\mathrm{a}}$ & $0.001^{b}$ & $0.001^{\mathrm{b}}$ & 0.082 & 0.163 & $0.002^{b}$ & 0.755 & $0.021^{\mathrm{a}}$ & $0.001^{b}$ & 0.445 & $0.001^{\mathrm{b}}$ \\
\hline & & & $\mathrm{T} \times \mathrm{S}$ & 8 & $0.021^{\mathrm{a}}$ & 0.127 & 0.243 & 0.422 & 0.876 & 0.341 & 0.230 & 0.790 & 0.451 & 0.648 & 0.632 \\
\hline
\end{tabular}

${ }^{1} \mathrm{~T}=$ TREATMENT $\mathrm{S}=\mathrm{STAND} ; \mathrm{T} \times \mathrm{S}=\mathrm{TREATMENT} \times \mathrm{STAND}$ interaction.

${ }^{2}$ Df: degree of freedom.

${ }^{\mathrm{a}} 0.01<p \leq 0.05$.

${ }^{\mathrm{b}} p \leq 0.01$.

$\mathrm{ND}=$ no data.

significantly in 1997 for both species (table VIII). This increase was however very limited, as the maximum difference between the CONTROL and the F2 treatment was $0.02 \%$ (spruce 1997, 2-year old needles) (table VIII).

An important decrease of mean $\mathrm{Al}$ foliar content was noticed 3 years after base cation fertilization, but it was only significant for spruce (both age classes of needles) (table VIII), probably because of a lower variability of $\mathrm{Al}$ concentrations for this species compared to beech (compare the 1997 coefficients of variation).

Foliar concentrations of $\mathrm{B}$ and $\mathrm{Zn}$ showed a distinct significant pattern. We noticed an important decrease of the B concentration 2 years after fertilization, this decrease tending to be higher in the F2-treated plots compared to the F1-treated plots (table IX). For the beech stands, the decrease was already significant in 1995 and remained significant in 1997 (tables VII and IX). As postulated by Gupta et al. (1985) and Kreutzer (1995), this phenomenon probably results from the formation of organic complexes, promoting the insolubilisation of B and low availability for plant uptake.

On the opposite, fertilization activated $\mathrm{Zn}$ uptake for spruce and beech. In the spruce stands, the TREATMENT effect was already significant in 1995 for both years of needles (table VII). In addition, mean $\mathrm{Zn}$ concentrations were higher for the F2- than for the F1treatments (table IX). The great inter-annual variability of $\mathrm{Zn}$ foliar concentrations must however be noticed. In the CONTROL treatment of the beech stands for instance, values reported for 1997 were about half those of 1995. These differences could be due to various factors such as climate or sampling variability. Contradictory results are found in the literature concerning the effects of 
Table VIII. Means (\% of dry matter) and coefficient of variation (CV\%) of the nutrient foliar concentrations by species, year and treatment.

\begin{tabular}{|c|c|c|c|c|c|c|c|c|c|c|c|c|c|}
\hline \multirow[t]{2}{*}{ Species } & \multirow[t]{2}{*}{ Year } & \multirow{2}{*}{$\begin{array}{l}\text { Age of } \\
\text { needles }\end{array}$} & \multirow[t]{2}{*}{ Treatment } & \multirow[t]{2}{*}{$\mathrm{Ca}$} & \multirow[b]{2}{*}{$\mathrm{CV}$} & \multirow[t]{2}{*}{$\mathrm{Mg}$} & \multirow{2}{*}{\multicolumn{2}{|c|}{$\mathrm{CV}$}} & \multirow[b]{2}{*}{$\mathrm{CV}$} & \multirow[t]{2}{*}{$\mathrm{P}$} & \multirow{2}{*}{\multicolumn{2}{|c|}{$\mathrm{CV}$}} & \multirow[b]{2}{*}{$\mathrm{CV}$} \\
\hline & & & & & & & & & & & & & \\
\hline \multirow[t]{12}{*}{ Spruce } & 1995 & 1 & Control & 0.20 & 9 & 0.08 . & 4 & 0.56 & 5 & 0.14 & 3 & 68.01 & 6 \\
\hline & & & $\mathrm{F} 1$ & 0.26 & 7 & 0.09 . & 4 & 0.55 & 5 & 0.14 & 3 & 65.13 & 6 \\
\hline & & & $\mathrm{F} 2$ & 0.27 & 7 & 0.08 . & 4 & $0.65 *$ & 4 & 0.15 & 3 & 67.94 & 6 \\
\hline & & 2 & Control & 0.21 & 8 & 0.06 . & 4 & 0.49 & 5 & 0.12 & 2 & 103.71 & 4 \\
\hline & & & F1 & 0.26 & 6 & 0.06 . & 4 & 0.50 & 5 & 0.12 & 2 & 101.11 & 5 \\
\hline & & & $\mathrm{F} 2$ & 0.25 & 7 & 0.06 . & 4 & $0.60 *$ & 4 & $0.14 *$ & 2 & 109.64 & 4 \\
\hline & 1997 & 1 & Control & 0.17 & 4 & 0.08 . & 4 & 0.48 & 3 & 0.16 & 2 & 52.31 & 3 \\
\hline & & & F1 & $0.29 *$ & 3 & $0.10 *$ & 3 & 0.45 & 3 & 0.15 & 2 & $43.76 *$ & 4 \\
\hline & & & $\mathrm{F} 2$ & $0.28 *$ & 3 & $0.09 *$ & 4 & $0.53 *$ & 3 & $0.17 *$ & 2 & $46.27 *$ & 4 \\
\hline & & 2 & Control & 0.18 & 7 & 0.05 & 6 & 0.40 & 4 & 0.13 & 2 & 79.13 & 3 \\
\hline & & & $\mathrm{F} 1$ & $0.32 *$ & 4 & $0.08 *$ & 4 & 0.39 & 4 & 0.14 & 2 & $61.28 *$ & 4 \\
\hline & & & $\mathrm{F} 2$ & $0.30 *$ & 4 & $0.06 *$ & 5 & 0.43 & 4 & $0.15 *$ & 2 & $65.97 *$ & 4 \\
\hline \multirow[t]{6}{*}{ Beech } & 1995 & & Control & 0.43 & 6 & 0.05 & 8 & 0.64 & 3 & 0.12 & 3 & 45.45 & 3 \\
\hline & & & $\mathrm{F} 1$ & $0.55 *$ & 4 & 0.06 . & 7 & 0.59 & 4 & 0.12 & 3 & 42.80 & 4 \\
\hline & & & $\mathrm{F} 2$ & $0.52 *$ & 5 & 0.06 . & 8 & 0.67 & 3 & 0.13 & 3 & 40.92 & 4 \\
\hline & 1997 & & Control & 0.30 & 5 & 0.07 & 8 & 0.54 & 6 & 0.13 & 3 & 38.31 & 9 \\
\hline & & & F1 & $0.50 *$ & 3 & $0.09 *$ & 6 & 0.50 & 7 & 0.13 & 3 & 31.66 & 11 \\
\hline & & & $\mathrm{F} 2$ & $0.47 *$ & 3 & $0.09 *$ & 7 & 0.56 & 6 & $0.14 *$ & 3 & 28.43 & 12 \\
\hline
\end{tabular}

* Significant difference compared to the control (Dunnett's test, $\alpha$ level $=5 \%$ ).

base cation fertilization on $\mathrm{Zn}$ foliar concentrations. Several authors report that $\mathrm{Zn}$ is less soluble in the soil and thus less available for the plant in case of $\mathrm{pH}$ increase [6]. According to Fiedler (1988), pH should not exceed 5.0-5.5 otherwise $\mathrm{Zn}$ availability would decrease considerably. On the other hand, data from studies on acid soils show an increase of $\mathrm{Zn}$ foliar concentration following lime application $[12,33]$. Synthetising these results, it seems that a moderate $\mathrm{pH}$ increase after base cation fertilization on acid soils is likely to produce an increase of Zn plant uptake. Bakker (1999) showed that the uptake of different micronutrients could be improved after fertilization by positive effect on mycorrhizae. With further increase in $\mathrm{pH}$, however, insolubilisation of soil $\mathrm{Zn}$ could cause a decrease in $\mathrm{Zn}$ availability.

As for the soil, the analyses of variance showed a significant STAND effect for most of the foliar chemical properties. On the other hand, the TREATMENT $\times$ STAND interaction was rarely significant (table VII). The effects of the treatments were strong enough to account for the similarities of response between stands, de- spite possible initial differences in stand and/or site conditions.

\section{CONCLUSIONS}

This study demonstrated that base cation fertilization may be an efficient tool to restore the soil and foliar chemical status of stands situated on acid and nutrient poor soils. Application of $3 \mathrm{tha}^{-1}$ of dolomite lime quickly corrected nutritional imbalances, which are known to be important contributing factors to forest dieback.

Preliminary soil and foliage analyses are necessary to select the appropriate treatments. For instance, it was shown that dolomite application alone tended to reduce $\mathrm{K}$ concentrations in the soils and the leaves of the beech stands. In case of low initial K concentrations, this could lead to induced deficiencies. Addition of even a low quantity of potassium sulphate (maximum $250 \mathrm{~kg} \mathrm{ha}^{-1}$ ) 
Table IX. Means ( $\mathrm{mg} \mathrm{kg}^{-1}$ of dry matter) and coefficient of variation $(\mathrm{CV} \%)$ of the nutrient foliar concentration by species, year and treatment.

\begin{tabular}{|c|c|c|c|c|c|c|c|c|c|c|c|c|c|c|c|}
\hline \multirow[t]{2}{*}{ Species } & \multirow[t]{2}{*}{ Year } & \multirow{2}{*}{$\begin{array}{l}\text { Age of } \\
\text { Needles }\end{array}$} & \multirow{2}{*}{$\begin{array}{l}\text { Treat- } \\
\text { ment }\end{array}$} & \multirow[t]{2}{*}{ B } & \multicolumn{3}{|c|}{$\mathrm{Cu}$} & \multirow[t]{2}{*}{$\mathrm{Fe}$} & \multicolumn{3}{|c|}{$\mathrm{Na}$} & \multirow[t]{2}{*}{$\mathrm{Zn}$} & \multicolumn{3}{|c|}{$\mathrm{N}$} \\
\hline & & & & & $\mathrm{CV}$ & & $\mathrm{CV}$ & & $\mathrm{CV}$ & & $\mathrm{CV}$ & & $\mathrm{CV}$ & & $\mathrm{CV}$ \\
\hline \multirow[t]{12}{*}{ Spruce } & 1995 & 1 & Control & 28.61 & 5 & ND & ND & 31.28 & 4 & ND & ND & 17.13 & 8 & 1.63 & 1 \\
\hline & & & F1 & 27.07 & 5 & ND & ND & 28.99 & 4 & ND & ND & 19.76 & 7 & 1.68 & 1 \\
\hline & & & $\mathrm{F} 2$ & 26.98 & 5 & ND & ND & 28.30 & 5 & ND & ND & $24.13^{*}$ & 6 & 1.66 & 1 \\
\hline & & 2 & Control & 23.22 & 5 & ND & ND & 33.64 & 5 & ND & ND & 10.96. & 8 & ND & ND \\
\hline & & & $\mathrm{F} 1$ & 22.77 & 5 & ND & ND & 34.87 & 5 & ND & ND & 12.87 & 7 & ND & ND \\
\hline & & & $\mathrm{F} 2$ & 21.76 & 6 & ND & ND & 34.36 & 6 & ND & ND & $15.88^{*}$ & 6 & ND & ND \\
\hline & 1997 & 1 & Control & 18.15 & 2 & 3.30 & 4 & 26.18 & 3 & 144.08 & 6 & 9.62 & 5 & 1.48 & 1 \\
\hline & & & $\mathrm{F} 1$ & $15.81^{*}$ & 3 & 3.15 & 4 & 27.16 & 3 & 154.54 & 6 & $15.59^{*}$ & 3 & 1.47 & 1 \\
\hline & & & $\mathrm{F} 2$ & $14.73 *$ & 3 & 3.63 & 4 & 28.04 & 3 & $194.13^{*}$ & 5 & $16.48^{*}$ & 3 & 1.49 & 1 \\
\hline & & 2 & Control & 15.48 & 3 & 2.70 & 6 & 31.77 & 2 & 150.33 & 5 & 7.17 & 9 & 1.47 & 1 \\
\hline & & & F1 & $12.51^{*}$ & 4 & $2.19^{*}$ & 7 & $29.60 *$ & 2 & 147.16 & 5 & $12.51^{*}$ & 5 & 1.47 & 1 \\
\hline & & & F2 & $11.83^{*}$ & 4 & 2.62 & 6 & 31.92 & 2 & 174.01 & 5 & $14.15^{*}$ & 5 & 1.45 & 1 \\
\hline \multirow[t]{6}{*}{ Beech } & 1995 & & Control & 29.80 & 3 & 4.78 & 7 & 83.59 & 4 & 167.50 & 7 & 18.36 & 7 & 2.17 & 1 \\
\hline & & & $\mathrm{F} 1$ & $24.74 *$ & 3 & $3.38 *$ & 10 & 76.55 & 4 & 143.49 & 8 & 20.37 & 7 & 2.16 & 1 \\
\hline & & & $\mathrm{F} 2$ & $23.07 *$ & 4 & $2.86^{*}$ & 13 & 75.90 & 5 & $118.35^{*}$ & 10 & 22.94 & 6 & 2.23 & 1 \\
\hline & 1997 & & Control & 19.48 & 3 & 5.59 & 14 & 47.51 & 6 & 116.95 & 5 & 10.89 & 5 & 2.22 & 2 \\
\hline & & & F1 & $16.50^{*}$ & 4 & 5.73 & 14 & 47.33 & 6 & 111.75 & 5 & $14.73^{*}$ & 4 & 2.15 & 2 \\
\hline & & & $\mathrm{F} 2$ & $15.77^{*}$ & 4 & 5.82 & 14 & 42.03 & 7 & 118.17 & 5 & $16.27 *$ & 4 & 2.14 & 2 \\
\hline
\end{tabular}

* Significant difference compared to the control (Dunnett's test, $\alpha$ level $=5 \%$ ).

$\mathrm{ND}=$ no data.

to dolomite proved to be a tool to avoid this problem. On the other hand, the addition of natural phosphate (maximum $800 \mathrm{~kg} \mathrm{ha}^{-1}$ ) did not result in any systematic increase in soil and foliar P concentrations.

For a given species, variations in site and/or ecoclimatic conditions only had a minor influence on the effects of base cation fertilization. This allows us to generalise the results of this study at the regional scale of the Belgian Ardenne for adult Norway spruce and European beech forests situated on acid brown soils.

Differences between species are to be taken into account when planning fertilizer treatment. Our study showed that migration of $\mathrm{Ca}-\mathrm{Mg}$ ions through the soil profile after dolomite application was more rapid for the spruce than for the beech stands. On the other hand, dolomite tended to reduce soil and leave K concentration only in the beech stands. Better understanding of the contrasting pattern observed between the two species would need more detailed studies. In addition, it should be important to assess the response of stands to base cation fertilization on larger time scale before concluding unequivocally about these results.

Another important issue of this study concerns the indirect effect of base cation fertilization on micronutrient nutrition. Particularly, it has been shown that the $\mathrm{Zn}$ foliar content increased and that the B foliar concentration decreased following application of the treatments. Risks of induced $\mathrm{Zn}$ toxicity and induced B deficiency should be investigated.

Acknowledgements: This study was conducted with the support of the "Division de la Nature et des Forêts" of the Walloon Region and the European Commission. We would like to thank Julien Lievens, Frédéric Hardy, Olivier Bouchez, François Plume, Louis Gerlache, Karine Henin, Vivianne Van Hese, as well as local foresters for their assistance during the fieldwork. We also would like to thank two anonymous reviewers for their constructive comments on an earlier version of this manuscript. 


\section{REFERENCES}

[1] Andersson F., Nihlgard B., Forest liming: goals and means, in: Andersson F. and Persson T. (éd.), Liming as a Measure to Improve Soil and Tree Condition in Areas Affected by Air Pollution, National Swedish Environmental Protection Board, Report 3518, Solna, 1988, pp. 14-19.

[2] Bakker M.R., Nys C., Effects of lime-induced differences in site fertility on fine roots of oak, Ann. For. Sci. 56 (1999) 599-606.

[3] Dagnélie P., Palm R., Rondeux J., Thill A., Tables de production relatives à l'épicéa commun (Picea abies (L.) Karsten), Les Presses Agronomiques de Gembloux, Gembloux, 1989.

[4] Dulière J.F., Carnol M., Dalem S., Remacle J., Malaisse F., Impact of dolomite lime on the ground vegetation and on potential net $\mathrm{N}$ transformations in Norway spruce (Picea abies (L.) Karst.) and sessile oak (Quercus petraea (Matt.) Lieb.) stands in the Belgian Ardenne, Ann. For. Sci. 56 (1996) 361-370.

[5] Flückiger W., Braun S., Revitalization of an alpine protective forest by fertilization, Plant Soil 168-169 (1995) 481-488.

[6] Fiedler H.J, The zinc supply of Norway spruce ecosystems in forest dieback areas, Beiträge für die Forstwirtschaft 22 (1988) 61-66.

[7] Geissen V., Rudinger C., Schoning A., Brummer G.W., Microbial biomass and earthworm populations in relation to soil chemical parameters in an oak-beech forest soil, Verhandlungen der Gesellschaft für Okologie 28 (1998) 249-258.

[8] Gupta U.C., Jame Y.W., Campbell C.A., Leystron A.J., Nikolaichuk W., Boron toxicity and deficiency: a review, Can. J. Soil. Sci. 65 (1985) 381-409.

[9] Hannick A.-F., Waterkeyn L., Weissen F., Van Praag H.J., Vascular tissue anatomy of Norway spruce needles and twigs in relation to magnesium deficiency, Tree Physiol. 13 (1993) 337-349.

[10] Horn R., Zech W., Hantschel R., Kaupenjohann M., Schneider B.U., Relations between soil properties and forest dieback, Allg. Forst. Zeit. 12 (1987) 300-302.

[11] Huettl R.F., Liming and fertilization as mitigation tools in declining forest ecosystems, Water Air Soil Pollut. 44 (1989) 93-118.

[12] Huettl R.F., Fink S., Lutz H.J., Poth M., Wisniewski J., Forest decline, nutrient supply and diagnostic fertilization in southwestern Germany and southern California, For. Ecol. Manage. 30 (1990) 341-350.

[13] ICP (International Co-operative Programme on Assessment and Monitoring of Air Pollution effects on Forest), Manual on methods and criteria for harmonized sampling, assessment, monitoring and analysis of the effects of air pollution on forest, Federal Research Center for Forestry and Forest Product (Hamburg), Forestry and Game Management Research Institute, Prague, 1994.

[14] Ingerslev M., Effects of liming and fertilization on growth, soil chemistry and soil water chemistry in a Norway spruce plantation on a nutrient-poor soil in Denmark, For. Ecol. Manage. 92 (1997) 55-66.

[15] Katzensteiner K., Eckmuellner O., Jandl R., Glatzel G., Sterba H., Wessely A., Huettl R.F., Revitalization experiments in magnesium deficient Norway spruce stands in Austria, Plant Soil 168-169 (1995) 489-500.

[16] Kreutzer K., Effect of forest liming on soil processes, Plant Soil 168-169 (1995) 447-470.

[17] Lambert J., Parmentier M., Léonard C., Weissen F, Reginster P., Premiers enseignements de l'analyse des sols forestiers en région wallonne, Silva Belgica 97 (1990) 7-12.

[18] Linder S., Foliar analysis for detecting and correcting nutrient imbalances in Norway spruce, Ecol. Bull. 44 (1995) 178-190

[19] Lindsay W.L., Chemical equilibria in soils, John Wiley and Sons, New York, 1979.

[20] Liu J.C., Huettl R.F., Relations between damage, symptoms and nutritional status of Norway spruce stands (Picea abies (L.) Karst.) in southwestern Germany, Fert. Res. 27 (1991) 9-22.

[21] Manion P.D., Tree disease concepts, Prentice-Hall, Englewood Cliffs, 1991.

[22] Misson L., du Bus de Warnaffe G., Jonard M., Effects of base cation fertilization on the ground vegetation of European beech and Sessile oak forests situated on acid brown soils (submitted to Ann. For. Sci.).

[23] Mohamed A.D., Ranger J., Dambrine E., Bonneau M., Gelhaye D., Granier A., The effects of limestone and of limestone plus NPK fertilization on the soil and mass balance of a spruce stand (Picea abies (L.) Karst.) in the Vosges mountains, For. Ecol. Manage. 60 (1993) 291-310.

[24] Nehlen N., Picard J.F., Influence de la fertilisation sur la végétation spontanée et la croissance radiale de l'épicéa commun (Picea abies (L) Karst.) dans une plantation adulte des Ardennes françaises, Ann. Sci. For. 51 (1994) 569-580.

[25] Noirfalise A., Forêts et stations forestières en Belgique, Les Presses Agronomiques de Gembloux, Gembloux, 1984.

[26] Onclincx F., Tanghe M., Galoux A., Weissen F., La carte des territoires écologiques de la Wallonie, Revue Belge de Géographie 1 (1987) 51-60.

[27] ONF, Bulletin Technique $\mathrm{N}^{\circ} 31$, Office National des Forêts, Paris, 1996.

[28] Ponette Q., Belkacem S., Nys C., Ion dynamics in acid forest soils as affected by addition of Ca fertilizers, Geoderma 71 (1996) 53-76.

[29] Ponette Q., Dufey J.E., Weissen F., Downward movement of dolomite, kieserite or a mixture of $\mathrm{CaCO}_{3}$ and kieserite through the upper layers of an acid forest soil, Water Air Soil Pollut. 95 (1997) 353-379.

[30] Ponette Q., Frankart R., Poma Rojas W., Petit C., Évolution physico-chimique d'un sol brun acide ardennais sous hêtraie suite à l'apport d'amendements minéraux, Pédologie 41 (1991) 89-100.

[31] SAS Institute Inc., SAS/Stat User's Guide, Version 6, Vol. 1, Cary, NC, USA, 1989. 
[32] Uebel E., Trillmilch H.D., Results of a pot experiment for determining the effect of applications of $\mathrm{N}, \mathrm{K}$ and $\mathrm{Mg}$ to a sandy soil on soil micro-organisms and the growth of pine seedlings, Pedobiologia 14 (1974) 41-50.

[33] Van Praag H.J., Weissen F., Foliar mineral composition, fertilization and dieback of Norway spruce in the Belgian Ardennes, Tree Physiol. (1986) 169-176.

[34] Weissen F., Dix ans plus tard : l'état de la question sur le dépérissement en forêt wallonne, Silva Belgica 103 (1996) 9-19.

[35] Weissen F., Hambuckers A., Van Praag H.J., Remacle J., A decennial control of $\mathrm{N}$-cycle in the Belgian Ardenne forest ecosystems, Plant Soil 28 (1990) 59-66.
[36] Weissen F., Letocart M., Van Praag H.J., Rapport préliminaire sur les effets de la pollution atmosphérique sur les forêts de l'Ardenne, Bull. Soc. Roy. For. Belgique 91 (1984) 61-72.

[37] Weissen F., Maréchal P., Le sol, un élément stabilisateur de l'écosystème forestier ardennais, Pédologie 51(1991) 69-87.

[38] Williams B.L., Nitrogen mineralization and organic matter decomposition in Scots pine humus, Forestry 45 (1972) $452-458$.

[39] Zoettl H.W., Huettl R.F., Fink S., Tomlinson G.H., Wisniewski J., Nutritional disturbances and histological changes in declining forests, Water Air Soil Pollut. 48 (1989) 87-109.

To access this journal online: www.edpsciences.org 